\title{
Seismic activity on the territory of Slovakia in 2018
}

Róbert KYSEL ${ }^{1,2, *}$, Andrej $\mathrm{CIPCIAR}^{1,2}$, Kristián $\mathrm{CSICSAY}^{1}$, Lucia FOJTÍKOVÁ ${ }^{1,4}$, Martin ŠUGÁR ${ }^{1,3}$, Jozef KRISTEK ${ }^{1,2}$

${ }^{1}$ Earth Science Institute of the Slovak Academy of Sciences, Dúbravská cesta 9, P. O. Box 106, 84005 Bratislava, Slovak Republic

${ }^{2}$ Faculty of Mathematics, Physics and Informatics, Comenius University in Bratislava, Mlynská dolina, 84248 Bratislava, Slovak Republic

${ }^{3}$ Faculty of Natural Sciences, Comenius University in Bratislava, Mlynská dolina, Ilkovičova 6, 84215 Bratislava, Slovak Republic

${ }^{4}$ Institute of Rock Structure and Mechanics of the Czech Academy of Sciences, V Holešovičkách 94/41, 182 09, Prague 8, Czech Republic

Abstract: The National Network of Seismic Stations of Slovakia (NNSS) consists of eight short period and five broadband permanent seismic stations and a data centre located at the Earth Science Institute of the Slovak Academy of Sciences (ESI SAS). The NNSS recorded and detected 11704 seismic events from all epicentral distances in 2018. Totally 86 earthquakes originated in the territory of Slovakia in 2018. This paper provides basic information on the configuration of the NNSS, routine data processing, seismic activity on the territory of Slovakia in 2018 as well as macroseismic observations collected in 2018.

Key words: Slovakia, National Network of Seismic Stations, seismicity, macroseismic observations

\section{Introduction}

The seismic activity on the territory of Slovakia and adjacent areas has been reported on the daily basis by the so called Seismo Reports published on the web sites of the Department of Seismology, ESI SAS http://www.seismo logy.sk/Seismo_Reports/reports.html and in annual reports as a part of the project Partial monitoring system - Geological factors (Liščák et al., 2019, in preparation) which is solved with a contract between ESI SAS and State Geological Institute of Dionýz Štúr. The aim of this paper is to provide a quick overview of earthquakes which originated on the territory of Slovakia or were macroseismically felt on the territory of Slovakia in 2018.

\footnotetext{
*corresponding author: e-mail: robert.kysel@savba.sk
} 


\section{Seismic stations operating in 2018}

The seismic monitoring of the Slovak territory is provided by the NNSS operated by the ESI SAS (ESI SAS, 2004), Local Seismic Network in Eastern Slovakia operated by the Faculty of Mathematics, Physics and Informatics of the Comenius University in Bratislava and local network of seismic stations around NPPs Jaslovské Bohunice and Mochovce operated by Progseis Ltd. company. The networks of seismic stations cooperate and the exchange of data is on the regular basis. The positions of the seismic stations on the territory of Slovakia are shown in Fig. 1.

In 2018 the NNSS consisted of thirteen permanent seismic stations, from which eight are short period and five are broadband. Broadband stations are: Červenica (CRVS), Kolonické sedlo (KOLS), Modra (MODS), Vyhne (VYHS) and Železná studnička (ZST). Short period stations are: Hurbanovo (HRB), Izabela (IZAB), Iža (SRO1), Kečovo (KECS), Liptovská Anna (LANS), Moča (SRO2), Stebnícka Huta (STHS) and Šrobárová (SRO). The HRB is the oldest NNSS seismic station that has been in operation since 1909 (Pajdušák, 1997). In 2018 the CRVS station was closed due to the changes in the property rights of the location site. A possibility to install a new station in the Šariš region has been investigated. The NNSS permanent

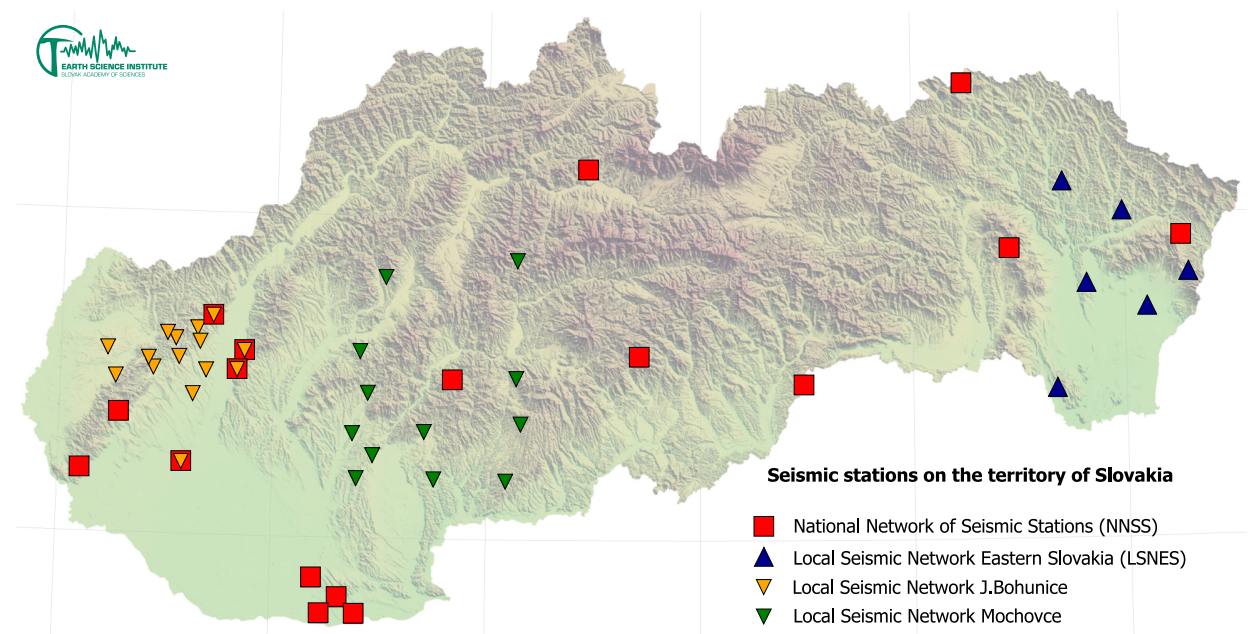

Fig. 1. Seismic stations operational on the territory of Slovakia in 2018. 
seismic stations and their instrumentation are summarized in Table 1. More details can be found on the web page http://www.seismology.sk/Nation al_Network.

Table 1. Equipment of seismic stations of the NNSS operating in 2018.

\begin{tabular}{|c|c|c|c|c|c|c|c|c|}
\hline Station & $\begin{array}{c}\text { ISC } \\
\text { code }\end{array}$ & $\begin{array}{c}\text { Lat. } \\
{\left[{ }^{\circ} \mathbf{N}\right]}\end{array}$ & $\begin{array}{c}\text { Long. } \\
{\left[{ }^{\circ} \mathbf{E}\right]}\end{array}$ & $\begin{array}{c}\text { Alt. } \\
{[\mathbf{m}]}\end{array}$ & Sensor & DAS & $\begin{array}{c}\text { Sampl. } \\
\text { freq. }\end{array}$ & $\begin{array}{c}\text { Data } \\
\text { format }\end{array}$ \\
\hline $\begin{array}{c}\text { Bratislava } \\
\text { Żel. Studnička }\end{array}$ & ZST & 48.196 & 17.102 & 250 & $3 \times$ SKD & Wave24 & $100 /$ sec & mSEED \\
\hline Červenica & CRVS & 48.902 & 21.461 & 476 & STS-2 & Wave24 & $100 /$ sec & mSEED \\
\hline Vyhne & VYHS & 48.493 & 18.836 & 450 & STS-2 & Wave24 & $100 /$ sec & mSEED \\
\hline Modra-Piesok & MODS & 48.373 & 17.277 & 520 & STS-2 & Wave32 & $100 /$ sec & mSEED \\
\hline Hurbanovo & HRB & 47.873 & 18.192 & 115 & $\begin{array}{c}2 \times \\
\text { Mainka }\end{array}$ & Analog & - & $\begin{array}{c}\text { smoked } \\
\text { paper }\end{array}$ \\
\hline Izabela & IZAB & 48.569 & 19.713 & 450 & $3 \times$ SM3 & Wave24 & $100 /$ sec & mSEED \\
\hline Iža & SRO1 & 47.7622 & 18.2328 & 111 & LE3D & PCM & $20 /$ sec & mSEED \\
\hline Kečovo & KECS & 48.483 & 20.486 & 345 & LE3D & Wave24 & $100 /$ sec & mSEED \\
\hline Kolonické sedlo & KOLS & 48.933 & 22.273 & 460 & $\begin{array}{c}\text { Guralp- } \\
6 \text { T-30s }\end{array}$ & Wave32 & $100 /$ sec & mSEED \\
\hline Liptovská Anna & LANS & 49.151 & 19.468 & 710 & LE3D & SEMS & $100 /$ sec & mSEED \\
\hline Moča & SRO2 & 47.763 & 18.394 & 109 & $\begin{array}{c}\text { Guralp- } \\
40 T-1 s\end{array}$ & Wave24 & $100 /$ sec & mSEED \\
\hline Stebnícka Huta & STHS & 49.417 & 21.244 & 534 & LE3D & Wave24 & $100 /$ sec & mSEED \\
\hline Šrobárová & SRO & 47.813 & 18.313 & 150 & $\begin{array}{c}3 \times \\
\text { SKM-3 }\end{array}$ & Wave24 & $100 /$ sec & mSEED \\
\hline
\end{tabular}

Four additional short period seismic stations has been operated on the jointly bases of ESI SAS and the other institutions. The seismic stations Banka (BAN), Podolie (POD) and Jalšové (JAL) located in the Little Carpathians have been operated in cooperation with Progseis Ltd. company and the Institute of Rock Structure and Mechanics of the Czech Academy of Sciences (IRSM CAS) (Fojtiková et al., 2015). The seismic station Pusté Úlany (PULA) has been operated in cooperation with the IRSM CAS. These stations have been installed as temporary seismic stations.

\section{Data processing}

Digital data from all NNSS stations (except the analog seismic station HRB) are transferred in real-time to the data centre at the ESI SAS either by the 
internet or satellite telemetry. Software package SeisComp3 (Weber et al., 2007) and SeedLink server are used for data acquisition and exchange.

Beside observations from the NNSS stations the data centre at ESI SAS also use the data from the above mentioned local networks of seismic stations in Slovakia and observations from networks of neighbouring countries: Austrian Seismic Network (ZAMG - Zentralanstalt für Meterologie und Geodynamik, 1987), Czech Regional Seismic Network (Institute of Geophysics, Academy of Sciences of the Czech Republic, 1973), Hungarian National Seismological Network (Kövesligethy Radó Seismological Observatory, 1992), Local seismological network for monitoring NPP Dukovany (Institute of Physics of the Earth Masaryk University, 2014), GEOFON Seismic Network (GEOFON Data Center, 1993), Polish Seismological Network. These stations form a so-called Regional Virtual Network of ESI SAS that consists of approximately 55 seismic stations.

Routine analysis of the digital recordings at the ESI SAS has been performed by the Unix package Seismic handler (Stammler, 1993). Interactive locations of seismic events within Seismic Handler are performed by external program LocSat. The collected digital observations are manually processed on the daily basis. The epicentre locations are based on the IASPI91 traveltime curves. Local magnitudes have been determined from the maximum vertical trace amplitudes of Sg waves, using the pre-defined Seismic Handler formula for local events. Continuous raw seismic data from the NNSS are stored in a local archive and seismic data interpretations (together with information on equipment of stations) are stored in a web accessible database.

\section{Seismic activity in 2018}

The NNSS analyzed 11704 local, regional and teleseismic events in 2018. More than 45800 seismic phases were determined. Seismic events identified as quarry blasts were excluded from further processing and were not included in the event statistics. All events recorded by the NNSS and analyses at the data centre at ESI SAS have been reported in the so called Seismo Reports and published on the above mentioned web sites of the Department of Seismology, ESI SAS.

Altogether 86 seismic events located by the NNSS originated in the territory of Slovakia in 2018 (Fig. 2). Known quarry blasts are not included in 


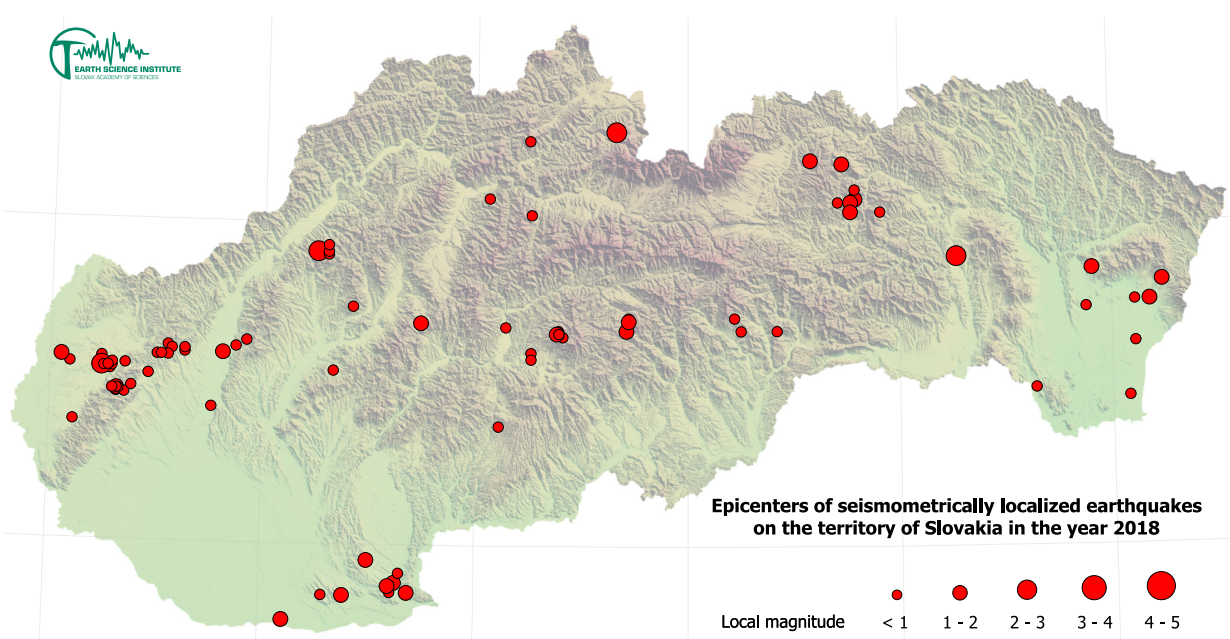

Fig. 2. Map of epicentres of local earthquakes originated on the territory of Slovakia in 2018. Diameters of the circles are proportional to local magnitudes.

this number. 31 earthquakes reached local magnitude 1.0 or more and are listed in Table 2. The strongest earthquake occurred on August 17 at 1:25 UTC in Strážovské Mts. with local magnitude $M_{L} 2.9$.

The seismicity of the Slovak territory is dominated by the Little Carpathians and Komárno seismic source zones (Hók et al., 2016). The strongest earthquake in the Little Carpathians source zone was detected on the May 7 at 21:23 UTC with local magnitude $M_{L}$ 1.3. The strongest earthquake in the Komárno source zone was detected on the January 17 at 5:49 UTC with local magnitude $M_{L}$ 2.0. Although the low level of seismic activity from the last decades remained unchanged in 2018, these two source zones remain of the primary interest for the monitoring of seismic activity within the territory of Slovakia.

\section{Macroseismic observations}

Five earthquakes were macroseismically felt on the territory of Slovakia in 2018 (Table 3), four of them with the epicentre on the territory of Slovakia and one with the epicentre in Poland (Fig. 3). All of these five earthquakes were also seismometrically observed and processed. Intensities were esti- 
Table 2. List of earthquakes originated on the territory of Slovakia in 2018 with $M_{L} \geq 1.0$.

\begin{tabular}{|c|c|c|c|c|c|c|c|}
\hline $\begin{array}{c}\text { Date } \\
{[\mathbf{Y Y Y Y}-\mathrm{MM}-\mathrm{DD}]}\end{array}$ & $\begin{array}{c}\text { Origin Time } \\
\text { (UTC) } \\
\text { [HH:MM:SS] }\end{array}$ & $\begin{array}{l}\text { Lat. } \\
{\left[{ }^{\circ} \mathbf{N}\right]}\end{array}$ & $\begin{array}{l}\text { Lon. } \\
{\left[{ }^{\circ} \mathbf{E}\right]}\end{array}$ & $\begin{array}{c}\text { Depth } \\
{[\mathrm{km}]}\end{array}$ & \begin{tabular}{|c}
$M_{L}$ \\
{$[\mathrm{NNSS}]$}
\end{tabular} & $\begin{array}{c}\boldsymbol{I}_{0} \\
{\left[{ }^{\circ} \mathbf{E M S}\right]}\end{array}$ & Region \\
\hline 2018-01-01 & 04:33:48.46 & 48.67 & 19.71 & 0 & 1.6 & felt & Vepor Mts. \\
\hline 2018-01-02 & $07: 28: 58.28$ & 48.70 & 19.72 & 0 & 1.1 & & Vepor Mts. \\
\hline 2018-01-12 & $15: 24: 13.62$ & 49.19 & 20.73 & 0 & 1.4 & & Levoča Mts. \\
\hline 2018-01-17 & $05: 49: 52.23$ & 47.84 & 18.39 & 0 & 2.0 & & $\begin{array}{l}\text { Šamorín - } \\
\text { Komárno - } \\
\text { Štúrovo }\end{array}$ \\
\hline 2018-01-31 & 11:16:09.62 & 49.08 & 20.79 & 0 & 1.8 & & Levoča Mts. \\
\hline 2018-02-25 & $13: 16: 32.77$ & 48.37 & 17.11 & 2.6 & 1.0 & & $\begin{array}{c}\text { Little } \\
\text { Carpathians }\end{array}$ \\
\hline 2018-03-13 & 20:05:11.06 & 48.69 & 18.74 & 0 & 1.8 & & Vtáčnik Mts. \\
\hline 2018-03-14 & $08: 48: 28.14$ & 47.95 & 18.50 & 0 & 1.1 & & Danubian Hills \\
\hline 2018-04-05 & 02:51:39.39 & 47.76 & 18.11 & 2.9 & 1.7 & felt & $\begin{array}{l}\text { Šamorín - } \\
\text { Komárno - } \\
\text { Štúrovo }\end{array}$ \\
\hline 2018-04-10 & 23:30:20.01 & 49.20 & 20.58 & 0 & 1.1 & & Levoča Mts. \\
\hline 2018-04-22 & $17: 10: 18.02$ & 48.82 & 22.24 & 4.4 & 1.4 & & Vihorlat Mts. \\
\hline 2018-04-26 & 13:04:46.31 & 48.59 & 17.81 & 0 & 1.2 & & $\begin{array}{c}\text { Považský Inovec } \\
\text { Mts. }\end{array}$ \\
\hline 2018-05-07 & $21: 23: 58.66$ & 48.47 & 17.31 & 0.6 & 1.3 & & $\begin{array}{c}\text { Little } \\
\text { Carpathians }\end{array}$ \\
\hline 2018-05-16 & 08:13:00.88 & 48.86 & 21.91 & 3.0 & 1.2 & & Vihorlat Mts. \\
\hline 2018-06-11 & 09:11:40.00 & 49.07 & 20.77 & 0 & 1.4 & & Levoča Mts. \\
\hline 2018-07-20 & $13: 44: 18.40$ & 49.04 & 20.77 & 0 & 1.2 & & Levoča Mts. \\
\hline 2018-08-17 & $01: 25: 12.86$ & 48.91 & 18.25 & 0.3 & 2.9 & 4 & Strážov Mts. \\
\hline 2018-08-24 & $14: 410: 43.75$ & 48.90 & 21.27 & 0 & 2.1 & & Slanské Hills \\
\hline 2018-09-11 & $17: 32: 02.68$ & 48.46 & 22.08 & 0 & 1.0 & & $\begin{array}{l}\text { East Slovak } \\
\text { Lowland }\end{array}$ \\
\hline 2018-10-02 & $21: 56: 53.28$ & 47.88 & 18.63 & 2.2 & 1.7 & & $\begin{array}{l}\text { Šamorín - } \\
\text { Komárno - } \\
\text { Štúrovo }\end{array}$ \\
\hline 2018-10-02 & $23: 22: 08.63$ & 47.85 & 18.69 & 0 & 1.2 & & Ipel' Hills \\
\hline $2018-10-14$ & $15: 37: 33.84$ & 48.67 & 19.39 & 0 & 1.0 & & Pol'ana \\
\hline
\end{tabular}


Table 2. Continued from the previous page.

\begin{tabular}{|c|c|c|c|c|c|c|c|}
\hline $\begin{array}{c}\text { Date } \\
{[\mathbf{Y Y Y Y}-\mathbf{M M}-\mathrm{DD}]}\end{array}$ & $\begin{array}{l}\text { Origin Time } \\
\text { (UTC) } \\
\text { [HH:MM:SS] }\end{array}$ & $\begin{array}{l}\text { Lat. } \\
{\left[{ }^{\circ} \mathbf{N}\right]}\end{array}$ & $\begin{array}{l}\text { Lon. } \\
{\left[{ }^{\circ} \mathbf{E}\right]}\end{array}$ & $\begin{array}{c}\text { Depth } \\
{[\mathrm{km}]}\end{array}$ & $\begin{array}{c}M_{L} \\
{[\mathrm{NNSS}]}\end{array}$ & $\begin{array}{c}\boldsymbol{I}_{0} \\
{\left[{ }^{\circ} \mathbf{E M S}\right]}\end{array}$ & Region \\
\hline 2018-10-17 & 04:32:13.12 & 48.66 & 19.38 & 0 & 1.3 & & Pol'ana \\
\hline 2018-11-06 & $14: 05: 14.03$ & 48.57 & 17.05 & 0 & 1.1 & & Záhorie region \\
\hline 2018-11-12 & 09:07:04.00 & 48.76 & 22.18 & 5.1 & 1.1 & & Vihorlat Mts. \\
\hline 2018-11-14 & $23: 16: 12.71$ & 49.29 & 19.66 & 0.8 & 2.1 & & High Tatras \\
\hline 2018-11-19 & 22:09:51.82 & 47.85 & 18.61 & 0 & 1.0 & & $\begin{array}{l}\text { Šamorín - } \\
\text { Komárno - } \\
\text { Štúrovo }\end{array}$ \\
\hline $2018-11-27$ & $22: 29: 37.37$ & 47.87 & 18.60 & 0 & 1.2 & & $\begin{array}{l}\text { Šamorín - } \\
\text { Komárno - } \\
\text { Štúrovo }\end{array}$ \\
\hline 2018-12-16 & 15:05:37.30 & 48.54 & 17.24 & 5.4 & 2.3 & 3 & Záhorie region \\
\hline $2018-12-17$ & 04:57:35.95 & 48.54 & 17.25 & 3.6 & 1.0 & & Záhorie region \\
\hline 2018-12-31 & 04:51:18.14 & 48.60 & 17.63 & 2.9 & 1.0 & & $\begin{array}{c}\text { Little } \\
\text { Carpathians }\end{array}$ \\
\hline
\end{tabular}

Table 3. List of macroseismically observed earthquakes on the territory of Slovakia in 2018.

\begin{tabular}{|c|c|c|c|c|c|c|c|}
\hline $\begin{array}{c}\text { Date } \\
\text { [YYYY-MM-DD] }\end{array}$ & $\begin{array}{c}\text { Origin Time } \\
\text { (UTC) } \\
{[\text { HH:MM:SS }]}\end{array}$ & $\begin{array}{c}\text { Lat. } \\
{\left[{ }^{\circ} \mathbf{N}\right]}\end{array}$ & $\begin{array}{c}\text { Lon. } \\
{\left[{ }^{\circ} \mathbf{E}\right]}\end{array}$ & $\begin{array}{c}\text { Depth } \\
{[\mathbf{k m}]}\end{array}$ & $\begin{array}{c}\boldsymbol{M}_{\boldsymbol{L}} \\
{[\mathbf{N N S S}]}\end{array}$ & $\begin{array}{c}\boldsymbol{I}_{0} \\
{\left[{ }^{\circ} \mathbf{E M S}\right]}\end{array}$ & Region \\
\hline $2018-01-01$ & $04: 33: 48.5$ & 48.68 & 19.71 & 0 & 1.6 & - & Vepor Mts. \\
\hline $2018-04-05$ & $02: 51: 39.4$ & 47.76 & 18.12 & 3 & 1.7 & - & Komárno \\
\hline $2018-07-15$ & $21: 19: 50.3$ & 49.34 & 20.93 & 7 & 2.6 & - & Krynica \\
\hline $2018-08-17$ & $01: 25: 12.9$ & 48.91 & 18.25 & 1 & 2.9 & 4 & Strážzov Mts. \\
\hline $2018-12-16$ & $15: 05: 37.3$ & 48.54 & 17.24 & 5 & 2.3 & 3 & Záhorie \\
\hline
\end{tabular}

mated by the European Macroseismic Scale 1998 (EMS-98) introduced by Grünthal (1998).

The earthquake on January 1 at 4:33 UTC with epicentre near Brezno and local magnitude 1.6 was macroseismically felt on 1 location (Table 4). Because of lack of macroseismic data it was not possible to determine the epicentral intensity. 


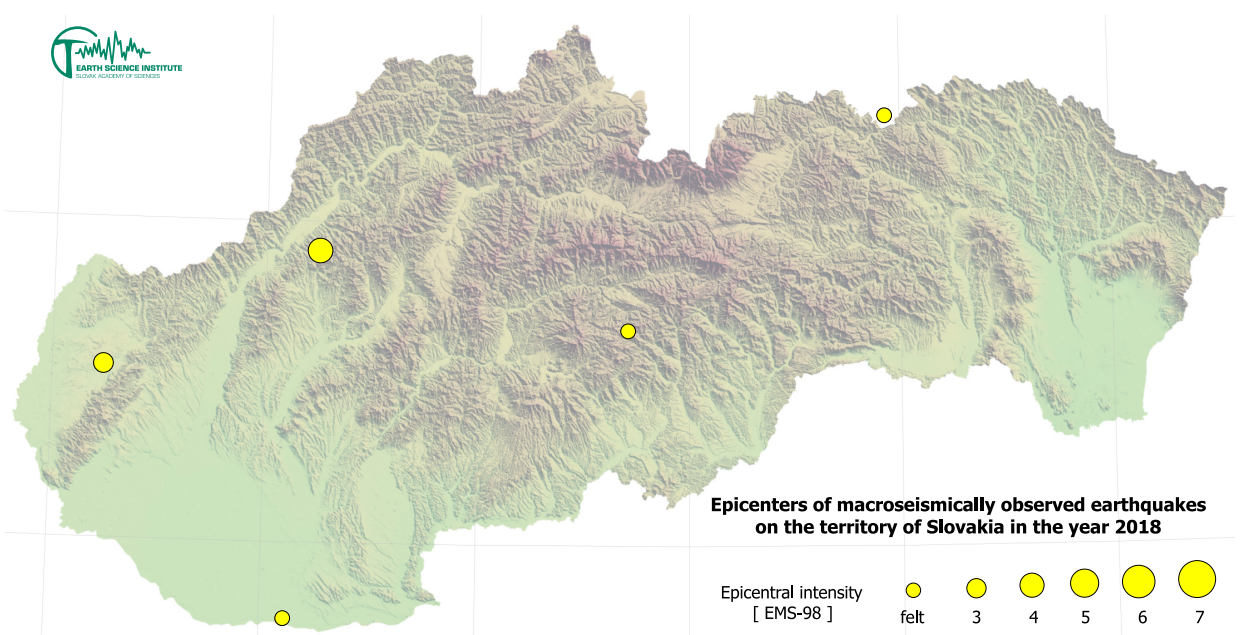

Fig. 3. Map of epicentres of macroseimically observed earthquakes on the territory of Slovakia in 2018. Diameters of the circles are proportional to epicentral intensity.

The earthquake on April 5 at 2:51 UTC with epicentre near Komárno and local magnitude 1.6 was macroseismically felt on 2 locations (Table 5). Because of lack of macroseismic data it was not possible to determine the epicentral intensity.

The earthquake on July 15 at 21:19 UTC with epicentre near Krynica, Poland and local magnitude 2.6 was macroseismically felt on 16 locations within the territory of Slovakia (Table 4). 47 macroseismic questionnaires were filled. People reported weak trembling or shaking and acoustic effects - rumbling. The maximum intensity on the territory of Slovakia was determined at $3-4^{\circ}$ EMS-98.

The earthquake on August 17 at 1:25 UTC with epicentre near Trenčianske Teplice and local magnitude 2.9 was macroseismically felt on 26 locations (Table 7). 178 macroseimic questionnaires were filled. The event was described as a light trembling. Some people reported acoustic effects - rumbling and fizzling. The epicentral intensity was determined at $4^{\circ}$ EMS-98.

The earthquake on December 16 at 15:05 UTC with epicentre in Záhorie region and local magnitude 2.3 was macroseismically felt on 4 locations (Table 8). 5 macroseimic questionnaires were filled. The event was described as a light trembling. The epicentral intensity was determined at $3^{\circ}$ EMS-98. 
Table 4. Macroseismic observations for January 1, 2018 earthquake, 4:33 UTC.

\begin{tabular}{|l|c|c|c|c|}
\hline Locality & $\begin{array}{c}\text { Lat. } \\
{\left[{ }^{\circ} \mathbf{N}\right]}\end{array}$ & $\begin{array}{c}\text { Lon. } \\
{\left[{ }^{\circ} \mathbf{E}\right]}\end{array}$ & $\begin{array}{c}\text { No. of } \\
\text { questionnaires }\end{array}$ & $\begin{array}{c}\boldsymbol{I} \\
{\left[{ }^{\circ} \mathbf{E M S}-98\right]}\end{array}$ \\
\hline Čierny Balog & 48.744 & 19.645 & 1 & felt \\
\hline
\end{tabular}

Table 5. Macroseismic observations for April 5, 2018 earthquake, 2:51 UTC.

\begin{tabular}{|l|c|c|c|c|}
\hline Locality & $\begin{array}{c}\text { Lat. } \\
{\left[{ }^{\circ} \mathbf{N}\right]}\end{array}$ & $\begin{array}{c}\text { Lon. } \\
{\left[{ }^{\circ} \mathbf{E}\right]}\end{array}$ & $\begin{array}{c}\text { No. of } \\
\text { questionnaires }\end{array}$ & $\begin{array}{c}\boldsymbol{I} \\
{\left[{ }^{\circ} \mathbf{E M S - 9 8}\right]}\end{array}$ \\
\hline Komárno & 47.766 & 18.118 & 1 & felt \\
\hline Nová Stráž & 47.764 & 18.044 & 1 & felt \\
\hline
\end{tabular}

Table 6. Macroseismic observations for July 15, 2018 earthquake, 21:19 UTC.

\begin{tabular}{|l|c|c|c|c|}
\hline Locality & $\begin{array}{c}\text { Lat. } \\
{\left[{ }^{\circ} \mathbf{N}\right]}\end{array}$ & $\begin{array}{c}\text { Lon. } \\
{\left[{ }^{\circ} \mathbf{E}\right]}\end{array}$ & $\begin{array}{c}\text { No. of } \\
\text { questionnaires }\end{array}$ & $\begin{array}{c}\text { I } \\
{\left[{ }^{\circ} \text { EMS-98 }\right]}\end{array}$ \\
\hline Malcov & 49.305 & 21.065 & 8 & $3-4$ \\
\hline Andrejovka & 49.288 & 20.901 & 1 & $3-4$ \\
\hline Hniezdne & 49.304 & 20.632 & 1 & $3-4$ \\
\hline Bardejov & 49.297 & 21.272 & 7 & 3 \\
\hline Kružlov & 49.311 & 21.136 & 4 & 3 \\
\hline Čirc & 49.282 & 20.924 & 1 & 3 \\
\hline Sveržov & 49.337 & 21.165 & 1 & 3 \\
\hline Hrabské & 49.320 & 21.070 & 6 & felt \\
\hline Kurov & 49.342 & 21.136 & 5 & felt \\
\hline Lenartov & 49.310 & 21.017 & 4 & felt \\
\hline Gerlachov & 49.098 & 20.210 & 3 & felt \\
\hline Snakov & 49.326 & 21.046 & 2 & felt \\
\hline Fričkovce & 49.186 & 21.245 & 1 & felt \\
\hline Gaboltov & 49.367 & 21.145 & 1 & felt \\
\hline Lipany & 49.156 & 20.964 & 1 & felt \\
\hline Lukov & 49.293 & 21.083 & 1 & felt \\
\hline
\end{tabular}

\section{Conclusion and discussion}

The NNSS is operated by the ESI SAS, Bratislava. Data from all stations (except station HRB) are transferred in real-time to the data centre at Bratislava. Data processing and routine analysis are performed digitally by in- 
Table 7. Macroseismic observations for August 17, 2018 earthquake, 1:25 UTC.

\begin{tabular}{|c|c|c|c|c|}
\hline Locality & $\begin{array}{l}\text { Lat. } \\
{\left[{ }^{\circ} \mathbf{N}\right]}\end{array}$ & $\begin{array}{l}\text { Lon. } \\
{\left[{ }^{\circ} \mathbf{E}\right]}\end{array}$ & $\begin{array}{c}\text { No. of } \\
\text { questionnaires }\end{array}$ & $\begin{array}{c}\boldsymbol{I} \\
{\left[{ }^{\circ} \text { EMS-98] }\right.}\end{array}$ \\
\hline Horná Súča & 48.980 & 17.950 & 1 & 4 \\
\hline Motešice & 48.824 & 18.183 & 1 & 4 \\
\hline $\begin{array}{l}\text { Dubnica nad } \\
\text { Váhom }\end{array}$ & 48.958 & 18.183 & 63 & 3 \\
\hline $\begin{array}{l}\text { Trenčianske } \\
\text { Teplice }\end{array}$ & 48.908 & 18.180 & 26 & 3 \\
\hline Omšenie & 48.902 & 18.226 & 6 & 3 \\
\hline $\begin{array}{l}\text { Trenčianska } \\
\text { Teplá }\end{array}$ & 48.937 & 18.121 & 6 & 3 \\
\hline Trenčín & 48.890 & 18.043 & 5 & 3 \\
\hline Nemšová & 48.970 & 18.115 & 3 & 3 \\
\hline $\begin{array}{l}\text { Košecké } \\
\text { Podhradie }\end{array}$ & 48.969 & 18.311 & 2 & 3 \\
\hline Báb & 48.307 & 17.872 & 1 & 3 \\
\hline Bojnice & 48.779 & 18.583 & 1 & 3 \\
\hline Bolešov & 49.000 & 18.170 & 1 & 3 \\
\hline Dobrá & 48.923 & 18.106 & 1 & 3 \\
\hline Kopec & 48.949 & 18.342 & 1 & 3 \\
\hline $\begin{array}{l}\text { Nové Mesto nad } \\
\text { Váhom }\end{array}$ & 48.758 & 17.829 & 1 & 3 \\
\hline Poriadie & 48.773 & 17.607 & 1 & 3 \\
\hline Pruské & 49.031 & 18.201 & 1 & 3 \\
\hline Púchov & 49.124 & 18.326 & 1 & 3 \\
\hline Nová Dubnica & 48.938 & 18.161 & 38 & felt \\
\hline Horná Poruba & 48.952 & 18.293 & 6 & felt \\
\hline Ilava & 48.982 & 18.243 & 6 & felt \\
\hline Dolná Poruba & 48.905 & 18.285 & 2 & felt \\
\hline Opatová & 48.914 & 18.096 & 1 & felt \\
\hline Prejta & 48.974 & 18.217 & 1 & felt \\
\hline $\begin{array}{l}\text { Vyškovce nad } \\
\text { Iplom }\end{array}$ & 48.072 & 18.864 & 1 & felt \\
\hline Žilina & 49.219 & 18.751 & 1 & felt \\
\hline
\end{tabular}


Table 8. Macroseismic observations for December 16, 2018 earthquake, 15:05 UTC.

\begin{tabular}{|l|c|c|c|c|}
\hline Locality & $\begin{array}{c}\text { Lat. } \\
{\left[{ }^{\circ} \mathbf{N}\right]}\end{array}$ & $\begin{array}{c}\text { Lon. } \\
{\left[{ }^{\circ} \mathbf{E}\right]}\end{array}$ & $\begin{array}{c}\text { No. of } \\
\text { questionnaires }\end{array}$ & $\begin{array}{c}\boldsymbol{I} \\
{\left[{ }^{\circ} \text { EMS-98 }\right]}\end{array}$ \\
\hline Prievaly & 48.558 & 17.350 & 2 & 3 \\
\hline $\begin{array}{l}\text { Bílikove } \\
\text { Humence }\end{array}$ & 48.586 & 17.238 & 1 & 3 \\
\hline Buková & 48.544 & 17.411 & 1 & 3 \\
\hline $\begin{array}{l}\text { Lakšárska Nová } \\
\text { Ves }\end{array}$ & 48.569 & 17.159 & 1 & 3 \\
\hline
\end{tabular}

teractive seismological software Seismic Handler. Digital data are accessible both on-line and off-line in standard data format. So called Seismo Reports of seismic events recorded by NNSS are published on the web page of the ESI SAS http://www.seismology.sk/SeismoReports/reports.html.

The lack of system approach to financing of the NNSS persisted also in 2018. The contribution from the budget of the Slovak Academy of Sciences is assigned for a day-to-day operation of the NNSS with insufficient additional funds for network improvement. In 2018 one new broadband sensor was purchased (the new sensor replaced the functionless one on VYHS station).

Epicentres and local magnitudes were determined for 86 earthquakes originated on the territory of Slovakia in 2018. Weak seismic activity was recorded from several seismic source zones: Little Carpathians, Komárno, Záhorie, Strážov Mts. and Vepor Mts.

Acknowledgements. The authors have been supported by the Slovak Foundation Grant VEGA 2/0144/19 and The Slovak Research and Development Agency Grant APVV-16-0146.

\section{References}

ESI SAS (Earth Science Institute of the Slovak Academy of Sciences), 2004: National Network of Seismic Stations of Slovakia. Deutsches GeoForschungsZentrum GFZ, Other/Seismic Network, doi: 10.14470/FX099882.

Fojtíková L., Kristeková M., Málek J., Sokos E., Csicsay K., Záhradník J., 2015: Quantifying capability of a local seismic network in terms of locations and focal mechanism 
solutions of weak earthquakes. J. Seismol., 20, 1, 93-106, doi : 10.1007/s10950-015 -9512-1.

GEOFON Data Center, 1993: GEOFON Seismic Network. Deutsches GeoForschungsZentrum GFZ, Other/Seismic Network, doi : 10.14470/TR560404.

Grünthal G. (Ed.), 1998: European Macroseismic Scale 1998 EMS-98. Cahiers du Centre Européen de Géodynamique et de Séismologie, 15, Luxembourg, 101 p., online, accessed 6 April 2019, available from: http://gfzpublic.gfz-potsdam.de/pubman/ item/escidoc:56109:4/component/escidoc :56108/EMS-98_Original_englisch_p df .pdf.

Hók J., Kysel R., Kováč M., Moczo P., Kristek J., Kristeková M., Šujan M., 2016: A seismic source zone model for the seismic hazard assessment of Slovakia. Geol. Carpath., 67, 3, 273-288, doi: 10.1515/geoca-2016-0018.

Institute of Geophysics, Academy of Sciences of the Czech Republic, 1973: Czech Regional Seismic Network. International Federation of Digital Seismograph Networks, Other/Seismic Network, doi: 10.7914/SN/CZ.

Institute of Physics of the Earth Masaryk University (Czech), 2014: IPE_EDU. International Federation of Digital Seismograph Networks, Other/Seismic Network, doi: $10.7914 /$ SN/D1.

Kövesligethy Radó Seismological Observatory (Geodetic and Geophysical Institute, Research Centre for Astronomy and Earth Sciences, Hungarian Academy of Sciences (MTA CSFK GGI KRSZO)), 1992: Hungarian National Seismological Network. Deutsches GeoForschungsZentrum GFZ, Other/Seismic Network, doi : 10.14470/UH 028726.

Liščák P., Petro L., Papčo J., Cipciar A., Csicsay K., Kristeková M., Stercz M., Pacajová K., Bednárik M., Briestenský M., Bella P., 2019: Partial Monitoring System Geological Factors, Subsystem 02: Tectonic and seismic activity of the territory, Geological work number 207, Report for 2018 (Čiastkový monitorovací systém Geologické faktory, Podsystém 02: Tektonická a seizmická aktivita, číslo geologickej úlohy 207, správa za obdobie: rok 2018). State Geological Institute of Dionýz Štúr, Regional centre Košice (in preparation).

Local Seismic Network of Eastern Slovakia. Faculty of Mathematics, Physics of the Earth and Informatics, Comenius University, html://www.fyzikazeme.sk/mainpage/ind ex_en.htm.

Pajdušák P., 1997: Historical seismic instruments at the stations Hurbanovo (HRB) and Skalnaté pleso (SPC) of Slovakia. Cahiers du Centre Européen de Géodynamique et de Séismologie, 13, 49-60.

Polish Seismological Network (PLSN), Institute of Geophysics Polish Academy of Sciences, https://www.igf.edu.pl/stacje-en.php.

Stammler K., 1993: Seismichandler-Programmable multichannel data handler for interactive and automatic processing of seismological analyses. Comput. Geosci., 19, 2, 135-140, doi : 10.1016/0098-3004 (93) 90110-Q.

Weber B., Becker J., Hanka W., Heinloo A., Hoffmann M., Kraft T., Pahlke D., Reinhardt J., Thoms H., 2007: SeisComp3 - automatic and interactive real time data processing. Geophysical Research Abstracts In EGU General Assembly, 9, 09129. 
ZAMG - Zentralanstalt für Meterologie und Geodynamik, 1987: Austrian Seismic Network. International Federation of Digital Seismograph Networks, Other/Seismic Network, doi : 10.7914/SN/OE. 